\title{
Prinsip Miranda Rules “The Right To Remain Silent” Dalam Perspektif Perbandingan Hukum
}

\author{
Pidel Kastro Hutapea dan Indra Karianga \\ pkhutapea@yahoo.com \\ Universitas Airlangga
}

\begin{abstract}
The principle of miranda rules "the right to remain silent" is a principle that is closely attached to the protection of human rights, especially against suspects. The research method used is legal research using a comparative approach which compares the legal norms set in the constitution between the State of Indonesia and the United States of America specifically regarding the principle of Miranda rules "the right to remain silent". The results of this study are that the basic concept of the rights of the suspect already exists in the constitutions of the USA and Indonesia that both require equality before the law, but in the law there are differences regarding the principle of the right to remain silent. Although there are differences in the legal events, but in terms of the constitution between the USA and Indonesia in line in regulating the protection of human rights including the right of the suspect to get legal protection. This shows the existence of the same passion between Indonesia and the USA in upholding human rights including the rights of the suspect. The existence of these equations makes it possible to include the right to remain silent as a whole in the procedural law in Indonesia as applicable in the USA.
\end{abstract}

Keywords: Principles; Miranda Rules; Rights; Suspects.

\begin{abstract}
Abstrak
Prinsip miranda rules "the right to remain silent" merupakan sebuah prinsip yang melekat erat pada perlindungan hak asasi manusia khususnya terhadap tersangka. Metode Penelitian yang digunakan yaitu legal research dengan menggunakan pendekatan perbandingan (comparative approach) yakni membandingkan norma hukum yang di atur dalam konstitusi antara Negara Indonesia dan Negara Amerika Serikat khususnya mengenai prinsip Miranda rules "the right to remain silent". Hasil dari penelitian ini yaitu konsep dasar hak tersangka sudah ada dalam konstitusi USA dan Indonesia yang sama-sama mengharuskan persamaan di depan hukum, namun dalam hukum acaranya terdapat perbedaan terkait prinsip the right to remain silent. Walaupun terdapat perbedaan dalam hukum acaranya, tetapi dari segi konstitusi antara USA dan Indonesia sejalan dalam mengatur terkait perlindungan hak asasi manusia termasuk hak tersangka untuk mendapatkan perlindungan hukum. Hal ini menunjukkan adanya semangat yang sama antara Indonesia dan USA dalam menjunjung tinggi hak asasi manusia termasuk di dalamnya hak tersangka. Adanya persamaan tersebut membuat dapat dimasukannya the right to remain silent secara menyeluruh dalam hukum acara di Indonesia sebagimana yang berlaku di USA.
\end{abstract}

Kata Kunci: Prinsip; Miranda Rules; Hak; Tersangka.

\section{Latar Belakang}

Hak untuk diam atau yang biasa dikenal dengan the right to remain silent merupakan bagian yang tak terpisahkan dari prinsip miranda rules. Prinsip miranda 
rules sendiri pertama kali ditetapkan di Amerika Serikat pada tahun 1966. ${ }^{1}$ Miranda rules awalnya muncul dari kasus Miranda di Arizona yang dituduh melakukan pemerkosaan dan tanpa penawaran mendapatkan advokat. Miranda menandatangani berita acara pemeriksaan tanpa didampingi advokat serta dipaksa untuk mengaku lewat tekanan verbal dalam proses interogasi, padahal dalam amandemen konstitusi Amerika Serikat, yakni amandemen ke V mengatur due process dan anti-kriminalisasi diri, serta dalam amandemen ke VI memberikan hak untuk didampingi oleh advokat. Pada kasus Miranda di dalamnya hakim mengatakan fakta bahwa ketika berlangsung proses interogasi di dalamnya hanya untuk menciptakan intimidasi kepada tersangka, walaupun bukan intimidasi fisik tapi suasana seperti itu merupakan pelecehan terhadap martabat manusia. ${ }^{2}$ Konsekuensi dari kasus Miranda tersebut kemudian menciptakan Miranda rules berupa hak untuk diam (the right to remain silent). Indonesia juga mengadopsi Miranda rights dalam Kitab Undang Hukum Acara Pidana (selanjutnya disingkat KUHAP) namun terdapat perbedaan dibandingkan dengan Miranda rights di Amerika Serikat, di mana Negara Amerika Serikat (selanjutnya disingkat USA) lewat putusan Mahkamah Agung USA maka kemudian hak untuk diam (the right to remain silent) menjadi kewajiban untuk diberitahukan penyidik terhadap tersangka sebelum pada saat proses interogasi dilakukan, hal tersebut dikenal sebagai Miranda warning yakni kewajiban penyidik untuk memberitahukan kepada tersangka sebelum dia diperiksa bahwa apa saja yang menjadi hak-haknya (Miranda rights). ${ }^{3}$ Indonesia dalam proses pemeriksaan penyidik tidak memberitahukan kepada tersangka bahwa tersangka mempunyai hak untuk diam. Hal ini adalah sebuah kewajaran karena dalam pasal 52 KUHAP hanya menyatakan bahwa:

"Dalam pemeriksaan pada tingkat penyidikan dan pengadilan, tersangka atau terdakwa berhak memberikan keterangan secara bebas kepada penyidik atau hakim."

1 M Sofyan Lubis, Prinsip Miranda Rights Hak Tersangka Sebelum Pemeriksaan (Pustaka Yustitia 2010).[16].

2 Munir Fuady dan Sylvia Laura, Hak Asasi Tersangka Pidana (Kencana 2015).[92].

3 ibid.[93]. 
Pasal 52 KUHAP hanya mengatur tersangka dan terdakwa bebas memberikan keterangan, namun tidak menyebutkan tersangka atau terdakwa berhak untuk diam atau tidak menjawab pertanyaan penyidik sebagaimana yang berlaku di USA. Hak untuk diam tidak secara eksplisit diatur di dalam KUHAP. Hal tersebut menimbulkan permasalahan, di mana dalam praktiknya seorang tersangka kadangkala dipaksa untuk mengaku telah melakukan perbuatan yang disangkakan kepadanya. Contohnya, dalam kasus pembunuhan Asrori tersangka pada faktanya tidak melakukan tindak pidana pembunuhan, namun kemudian dipukul oleh aparat oknum kepolisian untuk dipaksa mengaku telah melakukan pembunuhan terhadap korban dan akhirnya terpaksa tersangka mengakui telah membunuh Asrori. ${ }^{4}$ Dari kasus tersebut dapat dilihat bahwa tersangka tidak diberikan hak untuk tidak menjawab bahkan dilakukan pemukulan atau intimidasi secara fisik, sama halnya dengan Miranda di Arizona yang kemudian dipaksa mengaku lewat intimidasi verbal atau psikis. Atas dasar kasus Miranda tersebut kemudian USA memberikan terhadap tersangka hak untuk diam (rights to remain silent) sementara di Indonesia di dalam pasal 52 KUHAP hanya memberikan hak tersangka untuk bebas memberikan keterangan namun tidak ada perlindungan terhadap tersangka seperti yang berlaku di USA dengan berlakunya Miranda warning penyidik sebelum melakukan interogasi wajib meberitahukan hak-hak tersangka salah satunya hak untuk tidak menjawab (the right to remain silent).

Berdasarkan uraian di atas kemudian memunculkan isu hukum yaitu prinsip Miranda rules "the right to remain silent" dalam perspektif perbandingan hukum. Tujuan dari Perbandingan Hukum Prinsip Miranda Rule "The right to remain silent" adalah untuk melakukan Legal Reform dengan pendekatan perbandingan Hukum (legal konsep) di Indonesia dengan Amerika Serikat, yakni untuk memasukan secara eksplisit hak untuk diam bagi tersangka (the right to remain silent) dalam KUHAP yang pada saat ini sementara dibuat Rancangan Undang-Undang KUHAP. Urgensi dari dimasukannya prinsip Miranda rules "rights to remain silent" secara ekspisit

4 Vide: Putusan Pininjauan kembali No. 90/PK/PID/2008.[12]. 
ke dalam KUHAP adalah untuk memberikan perlindungan terhadap tersangka khususnya perlindungan dari intimidasi penyidik baik itu secara fisik maupun psikis. Hal ini penting karena seseorang tersangka belum tentu pada akhinya diputus bersalah, dapat saja akhirnya hakim memutuskan bebas (vrijspraak) atau lepas dari tuntutan hukum (onslag van recht vervolging) oleh karenanya berlaku asas praduga tak bersalah (presumption of innocence) yang merupakan bagian dari hak asasi setiap orang sebagaiman yang duat dalam Undang-Undang Nomor 39 Tahun 2009 tentang Hak Asasi Manusia, Pasal 18 dan di dalam ketentuan penjelasan umum KUHAP angka 3 huruf c menyatakan bahwa "setiap orang yang disangka, ditangkap, ditahan, dituntut dan atau dihadapkan di muka sidang pengadilan, wajib dianggap tidak bersalah sampai adanya putusan pengadilan yang menyatakan kesalahannya dan memperoleh kekuatan hukum tetap”. Hal ini menunjukan betapa pentingnya memperlakukan seorang tersangka sesuai dengan asas presumption of innocence yaitu salah satu caranya adalah dengan memberikan kepada tersangka the right to remain silent.

\section{Pembahasan}

Prinsip Miranda Rules "The Right To Remain Silent" Dalam Perspektif Perbandingan Hukum. Prinsip hukum Miranda rules diberlakukan dimulai pada tahap awal dalam penegakan hukum pidana yakni proses pemeriksaan di kepolisian. Hal tersebut kemudian menjadi suatu prosedur yang penting untuk ditaati oleh kepolisian yaitu penyelidik dan penyidik. Penanganan perkara oleh kepolisian menitik beratkan pada hukum dan ketertiban, sehingga memunculkan penafsiran ganda bagi kepolisian. Pertama adalah penggunaan hukum sebagai instrumen dari ketertiban di mana hukum pidana didalamnya memiliki perangkat hukum untuk memelihara ketertiban dalam masyarakat. Kedua, penggunaan hukum digunakan sebagai pembatas dari kesewenangan petugas penegak hukum dalam rangka melindungi kemerdekaan individu yang menjadi satu bagian dalam sistem 
ketertiban masyarakat. ${ }^{5}$ terkait hal itu Royal Commision menegaskan bahwa: ${ }^{6}$

"The Police should be powerful but not oppressive; they should be efficient but not officious; they should form an impartial force in the body politic, and yet subject to a degree of control by person who are not required to be impartial and who are themselves liable to police supervision."

Pendapat dari Royal Commision di atas menunjukan betapa pentingnya kepolisian dalam menjalankan tugas khususnya penegakan hukum baik dalam tingkat penyelidikan maupun penyidikan wajib untuk menjunjung tinggi asas imparsialitas. Kepolisian harus netral dalam menangani suatu kasus. Kepolisian dalam menjalankan tugasnya memiliki kewenangan tetapi hal tersebut digunakan bukan untuk menindas.

Romli Atmasasmita mengemukakan terkait law and order dalam peradilan pidana yakni terdapat empat poin penting. Pertama, kepribadian ganda yang mencakup penggunaan hukum sebagai instrumen ketertiban dalam masyarakat dan penggunaan hukum sebagai pembatas kekuasaan terhadap penegak hukum. Kedua, fokusnya terhadap law enforcement di mana hukum diutamakan dengan dukungan instansi kepolisian. Ketiga, keberhasilan dari penanggulangan kejahatan sangat tergantung pada efisiensi dan efektifitas petugas kepolisian. Poin terakhir adalah menimbulkan terkait diskresi dalam pelaksanaan tugas kepolisian. ${ }^{7}$ Dalam Undang-Undang Nomor 2 Tahun 2002 Tentang Kepolisian Negara Repuplik Indonesia Pasal 18 ayat (1) berbunyi "Yang dimaksud dengan "bertindak menurut penilaiannya sendiri" adalah suatu tindakan yang dapat dilakukan oleh anggota Kepolisian Negara Republik Indonesia yang dalam bertindak harus mempertimbangkan manfaat serta resiko dari tindakannya dan betul-betul untuk kepentingan umum.” Perlu diperhatikan poin terakhir yakni diskresi yang dilakukan kepolisian seyogianya haruslah menjunjung tinggi pada hak asasi manusia sebagaimana yang diatur dalam Peraturan Kepala Kepolisian Negara Republik Indonesia Nomor 8 Tahun 2009 Tentang Implementasi Prinsip Dan Standar Hak Asasi Manusia Dalam Penyelenggaraan Tugas Kepolisian

\footnotetext{
5 Romli Atmasasmita, Sistem Peradilan Kontemporer (Kencana 2010).[25].

6 ibid.[25].

7 ibid.[26].
} 
Negara Republik Indonesia. Hal ini mempertegas kembali prinsip pelaksanaan tugas kepolisian sebagaimana yang dikemukakan oleh Royal Commision dan sebagaimana yang dikemukakan pada poin pertama dari Romli Atmasasmita bahwasannya untuk membatasi kekuasaan yang berpotensi mengakibatkan tindakan kesewenangwenangan dari parat penegak hukum.

Uraian terkait prinsip dalam menjalankan tugas polri di atas selaras dengan fungsi dan tujuan dari hukum acara formil. Tujuan dari hukum acara pidana menurut Andi Hamzah adalah untuk mencari dan menemukan kebenaran materiil. Hal tersebut menunjukan adanya tujuan seluruh tertib (oder) hukum di Indonesia terkait dengan tujuan untuk menciptakan masyarakat yang tertib, damai, adil dan sejahtera. Fungsinya dikemukakan oleh Van Bemmelen bahwa hukum acara pidana pada dasarnya memiliki tiga fungsi pokok yakni yang pertama untuk mencari dan menemukan kebenaran. Kedua, pengambilan keputusan oleh hakim dan ketiga adalah pelaksanaan putusan dari hakim. ${ }^{8}$ Hukum acara pidana sebagai hukum formil yang mengatur terkait prosedural menjadi pedoman yang harus ditaati oleh penyelidik atau penyidik dalam melaksanakan tugas kepolisian. Norma yang terkandung di dalam hukum acara pidana adalah bevoegdheidsnormen atau norma kewenangan. Norma tersebut membatasi kewenangan aparat penegak hukum dalam penegakan hukum pidana umum khususnya dalam hal ini adalah kepolisian. Pembatasan peggunaan wewenang dalam norma tersebut di sisi lain melindungi hak-hak tersangka dalam proses penyidikan. ${ }^{9}$ Proses penyidikan merupakan proses yang penting dalam rangka mengungkap suatu kebenaran materiil, namun proses tersebut memungkinkan upaya paksa yakni upaya paksa berupa penangkapan maupun penahanan terhadap tersangka. Perkembangan dalam penegakan hukum yang mulai memikirkan hak asasi seorang tersangka memunculkan prinsip-prinsip yang mendukung terciptanya perlindungan tersangka atas dasar hak asasi manusia. Prinsip Miranda rules menempatkan tersangka bukan lagi sebagai objek tetapi sebagai subjek yang memiliki hak-hak dan hak-hak tersebut haruslah mendapatkan perlindungan.

8 Didik Endro Purwoleksono, Hukum Acara Pidana (Airlangga University Press 2015).[15].

9 ibid.[16]. 
Prinsip atau asas hukum merupakan hal yang penting harus dipertimbangan dalam menerapkan aturan hukum. Dworkin menjelaskan bahwa asas hukum tidak memiliki sifat alles of niets. ${ }^{10}$ Sering kali dalam kejadian atau sebuah peristiwa hukum dapat diterapkan berbagai asas hukum. Sehingga, penting untuk dipertimbangkan asas mana yang memiliki bobot paling relevan terhadap sebuah peristiwa hukum. ${ }^{11}$ Bruggink berpendapat bahwa pandangan Dworkin terlalu menitikberatkan pada perbedaan antara aturan hukum dan asas hukum. ${ }^{12}$ Dalam suatu peristiwa hukum hakim mengambil putusan berdasarkan fakta-fakta dari kejadian yang terjadi. Dari fakta-fakta tersebut asas-asas hukum berperan penting pada pengambilan keputusan yang akhirnya akan ditimbang mana yang paling tepat diterapkan terhadap kasus konkrit berdasarkan interpretasi aturan hukum yang digunakan. Dari sini memunculkan kesimpulan bahwa asas hukum merupakan meta-kaidah yang berkenaan dengan kaidah perilaku. ${ }^{13}$ Pendapat Dworkin dan Bruggink tersebut memberikan suatu gambaran terkait hakikat dari sebuah asas atau prinsip hukum. Prinsip atau asas hukum sebagai meta-kaidah dalam kasus konkrit haruslah menjadi rujukan prilaku aparat penegak hukum dalam memperlakukan tersangka sebagai subjek bukan objek sebagaimana yang melekat dalam prinsip Miranda rules.

Prinsip Miranda rules seperti yang telah penulis jelaskan di latar belakang bahwasanya miranda rules dimunculkan dari kasus Miranda di Arizona USA, di mana Miranda dituduh telah melakukan tindak pidana pemerkosaan dan selama proses pemeriksaan Miranda ditekan oleh penyidik untuk mengakui kesalahannya serta tidak diberikan penasihat hukum untuk mendampinginya selama proses pemeriksaan. ${ }^{14}$ Miranda rules kemudian dikenal sebagai suatu penghargaan kepada harkat dan martabat manusia. Negara yang hukumnya belum maju cenderung masih melakukan paksana secara fisik maupun pisikis agar tersangka mau untuk mengakui

10 JJ.H.Brugink, Refleksi Tentang Hukum Pengertian-Pengertian Dasar Dalam Teori Hukum (Citra Aditya Bakti 2015).[127].

11 ibid.[127].

12 ibid.[131-132].

13 ibid.

${ }^{14}$ Munir Fuady Dkk., Hak Asasi Tersangka Pidana (Kencana 2015). Loc.cit. [92]. 
perbuatannya. Pemaksaan terhadap tersangka untuk mengaku merupakan sebuah pelanggaran terhadap prinsip Miranda rules. ${ }^{15}$ Hakim dalam kasus Miranda tersebut mengatakan sebagai berikut:

"it is obvious that such an interrogation environment is created for no purpose other than to subjugate the individual to the will of his examiner. This atmosphere carries its own badge of intimidation to be sure, this is not physical intimidation, but it is equally destructive of human dignity". ${ }^{16}$

Pernyataan hakim kasus Miranda tersebut menegaskan dalam kasus Miranda sangat nyata bahwa proses interogasi yang dilakukan penyidik membuat tersangka untuk mengikuti kehendak penyidik dengan intimidasi secara verbal membuat Miranda mengakui perbuatannya. Meskipun intimidasi yang dilakukan bukan secara fisik tapi merupakan hal yang tidak dibenarkan secara kemanusiaan. Putusan hakim tersebut kemudian menciptakan Miranda rules yang merupakan perwujudan dari konsep kemerdekaan individu dan hak-hak tersangka dalam kesatuan yang tidak terpisahkan dari hak asasi manusia. Hak asasi manusia di Amerika Serikat dimuat dalam Amendment ke 14 (XIV) tentang Citizenship Rights. Ratified tahun 1868 angka 1 yang menyatakan bahwa:

"All persons born or naturalized in the United States, and subject to the jurisdiction thereof, are citizens of the United States and of the State wherein they reside. No State shall make or enforce any law which shall abridge the privileges or immunities of citizens of the United States; nor shall any State deprive any person of life, liberty, or property, without due process of law; nor deny to any person within its jurisdiction the equal protection of the laws". ${ }^{17}$

Amandemen konstitusi Amerika secara tegas melarang setiap Negara untuk merampas hak hidup "nor shall any State deprive any person of life" bahkan tidak hanya melarang setiap Negara untuk merampas hak hidup tetapi juga melarang setiap Negara dan setiap orang untuk merampas kemerdekaan "liberty" tanpa proses yang adil "due process of law" serta hak untuk mendapatkan perlindungan hukum yang sama dengan orang lain "equal protection of the laws". Konstitusi Negara Amerika Serikat secara tegas melarang adanya perampasan kemerdekaan serta

\footnotetext{
15 ibid.[93].

16 ibid.[92].

17 'The Constitution of the United States'.
} 
setiap orang wajib mendapatkan perlindungan yang sama oleh hukum. Due process of law menjadi suatu prinsip yang melekat dalam konstitusi sebagaimana konsep tersebut diterapkan dalam criminal justice system sebagaimana yang dikemukakan oleh Herbert L. Packer dalam bukunya the limits of the criminal sanction:

"In situation of necessity, it may be made by a police officer acting on probative data is subject to subsequent judicial scrutiny. Once a suspect has been arrested, he should be brought before a magistrate without unnecessary delay, which is to say as soon as it is physically possible to do so, once the preliminary formalities of recording his arrest have been completed". ${ }^{18}$

Pernyataan Packer di atas secara tegas menyatakan bahwa polisi sebagai penegak hukum atau haruslah memiliki bukti untuk menyatakan seseorang itu bersalah. Dalam prosesnya kemudian diawasi oleh hakim pengawas, sehingga due process of law menjadi syarat mutlak dalam proses penegakan hukum khususnya dalam melindungi hak-hak tersangka sebagaimana yang diatur dalam konstitusi Amerika Serikat Amandemen ke 14. Amerika Serikat dalam konstitusinya secara tegas mengatur perlindungan hak seseorang yang diduga melakukan tindak pidana agar mendapatkan perlindungan yang sama oleh hukum, sehingga terdapat persamaan dengan konstitusi di Negara Indonesia sebagaimana yang telah diatur dalam Undang-Undang Dasar Negara Republik Indonesia Tahun 1995 (Selanjutnya disingkat UUD RI 1945) pasal 28D ayat (1) menegaskan bahwa setiap orang berhak atas perlindungan, jaminan kepastian hukum yang adil serta perlakuan yang sama dihadapan hukum. Terdapat persamaan antara konstitusi Negara Amerika Serikat dan Indonesia yakni di Amerika Serikat memberikan perlindungan hukum yang sama bagi setiap orang tanpa mebedakan status, golongan, ras, dan sebagainya. Negara Indonesia juga mengatur hal yang sama dalam konstitusi pasal 28D secara tegas memberikan hak bagi setiap orang untuk mendapatkan perlindungan serta perlakukan yang sama dihadapan hukum sebagaimana yang telah dikenal dengan prinsip equality before the law. Persamaan antara konstitusi Negara Amerika Serikat dan

${ }^{18}$ Luhut MP Pangaribuan, Hukum Acara Pidana Suarat Resmi Advokat Di Pengadilan (Papas Sinar Sinanti 2014).[27]. 
Negara Indonesia menunjukan bahwa kedua Negara tersebut menjunjung tinggi hak asasi manusia termasuk di dalamnya hak-hak tersangka yang disangka melakukan tindak pidana untuk mendapatkan perlindungan yang sama tanpa membedakan statusnya sebagai korban atau sebagai tersangka.

Hak tersangka yang terkandung dalam Miranda rule merupakan bagian dari hak konstitusional karena konstitusi sendiri mengatur perlindungan hukum bagi setiap orang. Sebelum adanya Miranda rules di Amerika Serikat awal mulanya pengakuan tersangka diterima sebagai bukti yang sempurna walaupun pengakuan tersebut didapatkan dengan cara intimidasi terhadap tersangka. ${ }^{19}$ Sejak adanya pengakuan terhadap Miranda rules kemudian di Amerika Serikat dalam proses penegakan hukum kemudian menerapkan prinsip Miranda warning yakni sebelum melakukan interogasi kepada tersangka maka penyidik harus mengingatkan secara verbal terhadap tersangka bahwa tersangka mempunyai hak untuk tetap diam selama proses penyidikan (the right to remain silent), diingatkan kepada tersangka bahwa setiap keterangan yang diberikan kepada penyidik mungkin akan digunakan sebagai bukti yang nanti akan bertentangan dengan kepentingan tersangka, dan tersangka mempunyai hak untuk mendapatkan pembela (advokat) serta jika tersangka tidak mampu secara ekonomi untuk membayar jasa advokat maka Negara menyediakan advokat bagi tersangka. ${ }^{20}$ Miranda rights menjadi perwujudan dari perlindungan tersangka dalam setiap proses pemeriksaan yang harus dilalui sampai pada proses di pengadilan. Persamaan konstitusi USA dan Indonesia adalah sama-sama menjunjung tinggi hak asasi manusia karena hak asasi manusia tersebut dimuat dalam konstitusi kedua Negara, namun terdapat perbedaan yaitu dimuatnya prinsipprinsip Miranda rules salah satunya adalah hak untuk didampingi advokat berbeda. Amerika Serikat menaruh hak untuk didampingi oleh Advokat sebagaimana yang diatur di konstitusi USA Amandemen ke VI:

"In all criminal prosecutions, the accused shall enjoy the right to a speedy and public trial, by an impartial jury of the State and district wherein the crime shall

\footnotetext{
${ }^{19}$ Munir Fuady Dkk. (n 14).Op.cit.[78].

${ }^{20}$ ibid.[58].
} 
have been committed, which district shall have been previously ascertained by law, and to be informed of the nature and cause of the accusation; to be confronted with the witnesses against him; to have compulsory process for obtaining witnesses in his favor, and to have the Assistance of Counsel for his defence". ${ }^{21}$

Konstitusi amandemen ke VI USA secara gamblang dan eksplisit mewajibkan seorang tersangka untuk mendapat bantuan advokat guna kepentingan pembelaan tersangka "to have the Assistance of Counsel for his defence". Tidak hanya mendapatkan pengacara atau advokat tapi tersangka juga dalam proses pemeriksaan wajib diberikan hak untuk memperoleh saksi yang meringankan "to have compulsory process for obtaining witnesses in his favor" dalam hukum pidana dikenal dengan istilah saksi a de charge. Perbedaan di Indonesia hal tersebut tidak diatur dalam konstitusi UUD RI 1945 seperti di USA melainkan diatur dalam KUHAP yakni pada Pasal 65 KUHAP (hak mengajukan saksi $a$ de charge) dan hak untuk didampingi oleh pengacara atau advokat Pasal 56 KUHAP bagi tersangka dengan ancaman hukuman penjara 15 tahun, hukuman seumur hidup atau hukuman mati dan bagi yang tidak mampu dengan ancaman pidana penjara 5 tahun atau lebih wajib disediakan advokat. Ketentuan dalam Pasal 114 KUHAP di mana pada saat tersangka diperiksa penyidik wajib memberitahukan hak tersangka untuk didampingi oleh advokat. (Miranda warning). ${ }^{22}$ Walaupun terapat kewajiban penyidik untuk memberitahukan hak untuk didampingi oleh advokat yang merupakan salah satu prinsip dari Miranda rules, namun penyidik tidak wajib memberitahukan hak tersangka untuk diam (the right to remain silent) seperti yang berlaku di USA. Dengan diaturnya hak untuk didampingi oleh advokat serta hak untuk bebas memberikan keterangan (Pasal 52 KUHAP) bahkan hak untuk tidak menjawab (Pasal 175 KUHAP) dan Miranda warning (Pasal 114 KUHAP) menunjukkan Indonesia menganut prinsip Miranda rules.

21 'The Constitution of the United States' (n 17).

${ }^{22}$ Undang-Undang Nomor 8 Tahun 1981 Tentang Kitab Undang Hukum Acara Pidana, pasal 114: "Dalam hal seorang disangka melakukan suatu tindak pidana sebelum dimulainya pemeriksaan oleh penyidik, penyidik wajib memberitahukan kepadanya tentang haknya untuk mendapatkan bantuan hukum atau bahwa ia dalam perkaranya itu wajib didampingi oleh penasihat hukum sebagaimana dimaksud dalam Pasal 56". 
Permasalahan muncul dikarenakan prinsip Miranda rules yang diatur oleh Indonesia tidak seluruhnya diadopsi, padahal konsep Miranda rules USA yang didalamnya terdapat Miranda rights yakni hak untuk diam, hak untuk didampingi pengacara dan hak untuk diingatkan bahwa keterangan yang dia berikan dapat digunakan sebagai bukti yang dapat bertentangan dengan kepentingan tersangka. Semua hak tersebut diberitahukan sebelum dimulai interogasi "Miranda warning" dan merupakan kesatuan dengan Miranda rules. Hak untuk diam dalam Pasal 175 KUHAP hanya berlaku bagi terdakwa tidak bagi tersangka. ${ }^{23}$ Perbedaan dengan di USA hak untuk diam "the right to remain silent" diberikan terhadap seseorang mulai pada waktu orang tersebut berstatus sebagai tersangka (pemeriksaan awal penyelidikan atau penyidikan) bukan sebagai terdakwa. Hukum acara yang berlaku di Negara Indonesia, jika terdakwa tidak mengaku hakim dapat memasukkan hal tersebut sebagai hal yang memberatkan sebagaimana diatur dalam Pasal 8 ayat (2) Undang-Undang Nomor 48 Tahun 2009 tentang Kekuasaan Kehakiman. ${ }^{24}$ Contohnya dalam kasus pembunuhan dengan sianida, terdakwa pada waktu itu tidak mengakui perbuatannya, sehingga menjadi salah satu alasan yang memberatkan terdakwa. ${ }^{25}$ padahal terdapat prinsip non self incrimination sehingga seorang tersangka tidak dapat memberikan keterangan yang memberatkan atau merugikan dirinya, oleh karena itu ketika terdakwa memberikan keterangan dia tidak disumpah.

\section{Kesimpulan}

Perbandingan hukum antara Negara Amerika Serikat dengan Negara Indonesia dilihat dari persamaan adalah sama-sama menjunjung tinggi hak asasi manusia dan hak tersangka sebagimana dalam konstitusi USA amandemen ke XIV sama dengan

${ }^{23}$ Pasal 175 KUHAP “jika terdakwa tidak mau menjawab atau menolak untuk menjawab pertanyaan yang diajukan kepadanya, hakim ketua sidang menganjurkan untuk menjawab dan setelah itu pemeriksaan dilanjutkan".

${ }^{24}$ Undang-Undang Nomor 48 Tahun 2009 tentang Kekusaan Kehakiman "Dalam mempertimbangkan berat ringannya pidana, hakim wajib memperhatikan pula sifat yang baik dan jahat dari terdakwa".

${ }_{25}$ Putusan Pengadilan Negeri Jakarta Pusat No.777/Pid.B/2016/PN.JKT.PST.[369]. 
UUD RI 1945 pasal 28I ayat (1) jo Pasal 28D. ${ }^{26}$ Konsep dasar hak tersangka sudah ada dalam konstitusi USA dan Indonesia yang sama-sama mengharuskan equality before the law yaitu persamaan di depan hukum. Perbedaan yang didapatkan antara USA dan Indonesia adalah USA menerapkan Miranda warning yang di dalamnya mencakup the right to remain silent. Berbeda dengan di Indonesia di mana tersangka hanya dikatakan memberikan keterangan dengan bebas namun tidak secara eksplisit memberikan hak untuk diam yang tentunya berbeda dengan di USA bahwa saat diperiksa tersangka berhak untuk diam. Persamaan konstitusi mengenai hak asasi manusia antara USA dan Indonesia menunjukan adanya semangat menjunjung tinggi hak asasi manusia sehingga memungkinkan untuk dimasukannya the right to remain silent dalam KUHAP karena hal tersebut akan melindungi hak asasi manuisa yang merupakan semangat kedua Negara untuk melindungi hak warga Negara khususnya bagi warga Negara yang sedang menjalani proses hukum sebagai tersangka diberlakukan presumption of innocence sehingga hal the right to remain silent dapat dimasukkan dalam norma hukum pidana formil. Hal yang perlu dilakukan legal reform secara eksplisit adalah ketentuan Pasal 175 KUHAP di mana hanya diperuntukkan bagi terdakwa sehingga tersangka tidak diberikan hak untuk diam, oleh karenanya diperlukan adanya Legal Reform terhadap ketentuan Pasal 175 KIHAP agar dirubah bukan hanya bagi terdakwa tapi juga bagi tersangka seperti yang berlaku di Amerika Serikat. Legal Reform terhadap ketentuan Pasal 175 KUHAP akan memberikan perlindungan hukum terhadap tersangka dalam menjalani proses pemeriksaan. Legal Reform juga diperlukan terhadap ketentuan Pasal 8 ayat (2) Undang-Undang Nomor 48 Tahun 2009 tentang Kekuasaan Kehakiman agar memberikan batasan kepada hakim, berupa pengecualian yakni jika terdakwa tidak mengakui perbuatannya hal tersebut merupakan hak dari terdakwa oleh karena itu tidak dapat dijadikan alasan yang memberatkan terdakwa sebagaimana konsep Miranda rules yang memberikan hak untuk diam. Ketika tersangka atau terdakwa mengaku

${ }^{26}$ Undang-Undang Dasar Negara Republik Indonesia Tahun 1995 pasal 28I ayat (1) "Hak untuk hidup, hak untuk tidak disiksa, hak kemerdekaan pikiran dan hati nurani, hak beragama, hak untuk tidak diperbudak, hak untuk diakui sebagai pribadi dihadapan hukum, dan hak untuk tidak dituntut atas dasar hukum yang berlaku surut adalah hak asasi manusia yang tidak dapat dikurangi dalam keadaan apa pun". 
hal tersebut harus dilakukan dengan cara sukarela tanpa adanya intimidasi secara fisik maupun psikis. Ditambahkan the right to remain silent dalam ketentuan Pasal 175 KUHAP membuat tersangka benar-benar bebas memberikan keterangan karena kebebasan terdakwa salah satunya adalah dapat memilih untuk tidak menjawab atau memiliki the right to remain silent.

\section{Daftar Bacaan}

\section{Buku}

Atmasasmita R, Sistem Peradilan Kontemporer (Kencana 2010).

JJ.H.Brugink, Refleksi Tentang Hukum Pengertian-Pengertian Dasar Dalam Teori Hukum (Citra Aditya Bakti 2015).

M Sofyan Lubis, Prinsip Miranda Rights Hak Tersangka Sebelum Pemeriksaan (Pustaka Yustitia 2010).

Munir Fuady dan Sylvia Laura, Hak Asasi Tersangka Pidana (Kencana 2015).

Munir Fuady Dkk., Hak Asasi Tersangka Pidana (Kencana 2015).

Pangaribuan LMP, Hukum Acara Pidana Suarat Resmi Advokat Di Pengadilan (Papas Sinar Sinanti 2014).

Purwoleksono DE, Hukum Acara Pidana (Airlangga University Press 2015).

\section{Perundang-undangan}

Undang-Undang Nomor 8 Tahun 1981 Tentang Hukum Acara Pidana.

Undang-Undang Nomor 48 Tahun 2009 tentang Kekusaan Kehakiman.

Undang-Undang Dasar Negara Republik Indonesia Tahun 1995.

'The Constitution of the United States'.

\section{Putusan Pengadilan}

Putusan Pengadilan Negeri Jakarta Pusat No.777/Pid.B/2016/PN.JKT.PST.

Putusan Pininjauan kembali No. 90/PK/PID/2008.

HOW TO CITE: Pidel Kastro Hutapea dan Indra Karianga, 'Prinsip Miranda Rules "The Right To Remain Silent” Dalam Perspektif Perbandingan Hukum' (2019) Vol. 2 No. 3 Media Iuris. 